\title{
Can children's religiosity be built through family's religious culture and the discipline in attending TPA?
}

\author{
Tampi Prehadini *, Anwar Senen, Ali Mustadi \\ Department of Primary Education, Graduate School of Universitas Negeri Yogyakarta. \\ Jalan Colombo No. 1, Yogyakarta 55281, Indonesia \\ * Corresponding Author. E-mail: publisher.tampipd27@gmail.com
}

Received: 3 November 2020; Revised: 11 November 2020; Accepted: 15 December 2020

\begin{abstract}
This study aims to find out the effects of family's religious culture and the discipline in attending 'Taman Pendidikan Al Qur'an (TPA) at school on the first-grade students' religiosity. This study used the ex-post facto quantitative approach. The population was all first-grade student in Pengasih District, Kulon Progo regency with a total of 585 students, while the sample were taken randomly stratified. The technique for collecting data was using three questionnaires, such as students' religiosity, family's religious culture, and the discipline in attending TPA questionnaire. The analysis of prerequisite test that had been used are the normality, linearity, and multi-collinearity test. Data analysis that used was multiple regression. The result shows that: (1) family's religious culture partially gives significant effect on first-grade students' religiosity; (2) the discipline in attending TPA partially doesn't give significant effect on first-grade students' religiosity; and (3) family's religious culture and the discipline in attending TPA simultaneously give significant effect on first-grade students' religiosity with the effect is $5.2 \%$. It means that the better family's religious culture, the easier it to instill religious character. To make it balance, school has to reconsider TPA schedule to be effective in instilling their religiosity.
\end{abstract}

Keywords: students' religiosity, family's religious culture, the discipline in attending TPA at school.

How to Cite: Prehadini, T., Senen, A., \& Mustadi, A. (2021). Can children's religiosity be built through family's religious culture and the discipline in attending TPA at school?. Jurnal Prima Edukasia, 9(1), 145-157. doi:https://doi.org/10.21831/jpe.v9i1.35484

\section{Introduction}

Spiritual in the form of religiosity development is needed by all people in this world (Erick, 2013, p.1096). The revival of religious practice has become an important topic in social life, attracting serious attention both domestically and internationally (Cao, 2018, p.137). Six religions namely Islam, Christian, Catholic, Buddhism, Hinduism, and Confucianism are legally recognized in Indonesia according to Article 1 Law No.1 of Presidential Decree of 1965 on Blasphemy of Religion (UndangUndang Nomor 1 Penetapan Presiden Tahun 1965 Tentang Penodaan Agama). All levels of society and social institutions are expected to participate in cultivating the religious awareness of each individual, considering that religion will be the basis for decision making in social life (Fam et al., 2004, p.537555). Believing in religion is not enough by just believing in it, but it takes practice in life. A sad thing happens when a person claims to have a religion only in confession, but in his life, he does not have the attitudes, views, and behavior in accordance with the teachings of his religion. (Azzet, 2011, p.88).

Religious values are the values that underlie character education because basically Indonesia is a religious country, this is in accordance with the results of a survey conducted by the Pew Research Center in July 2020 which the result shows that Indonesia has second rank after Philippines as a religious country ini Southeast Asia (Iswara, 2020). Religious character underlies the other seventeen characters, which are: (1) honest; (2) tolerant; (3) discipline; (4) hard-working; (5) creative; (6) independent; (7) democratic; (8) curious; (9) having national spirit; (10) patriotic; (11) aprreciate achievement; (12) communicative; (13) peace-loving; (14) fond of reading; (15) care for the environment; 16) social care; and 17) responsibile. The eighteen characters developed in Indonesia almost same with Oklahoma in United State of America where it is necessary for educators to help children in the development of the most common and broad positive character traits, such as responsibility, caring for self and friends, perseverance, citizenship, discipline, honesty, courage, fairness, respect, patriotism, and integrity. Such 
character can ultimately promote proper ideas, attitudes, thinking, decision making, and behavior towards other (Stedje, 2013, p.55).

Religiosity is not an all or none equality but every individual has a certain degree of it. Religiosity is an umbrella term referring to degrees of religious behavior, belief, or spirituality (Khan, 2018, p.68). The essence of religiosity is the attitude and behavior that is being obedient in implementing the teachings of the religion, is tolerant of the worship of other religions, and lives in harmony with adherents of other religions (Wibowo \& Gunawan, 2015, pp. 43-44). Specifically, (Glock \& Stark, 1966, p.14) concluded that religiosity is an attitude of surrendering oneself to a force from outside himself which is manifested in daily activities and expressed in its aspects. Moreover, the religious dimension consists of five important points. First, the aspect of religious belief, that is the belief in God and everything related to the supernatural world and accepting dogmatic matters in the religious teachings. Second, the aspect of worship (religious practice), which is the aspect related to the level of attachment which includes the frequency and intensity of a number of behaviors, where the behavior has been determined by religion. Third, the aspect of appreciation (religious feeling), that is how far a person can appreciate the experience in religious rituals that he does. Fourth, the aspect of knowledge (religious knowledge) is related to a person's knowledge and understanding of his religious teachings. Fifth, the aspect of experience (religious effect), which is the application of knowledge from the teachings of the religion he adheres to then applied in the form of attitudes and behavior in everyday life. Thus, it can be concluded that religious character or religiosity is the manifestation of a set of life provisions that are inherent in the attitude and behavior of obeying the practice of religious teachings, being tolerant of other religions, and being able to live in harmony with followers of other religions so that human life can be organized.

Studies related to the importance of religious values can be started by contemplating how 'religion' is considered a fundamental thing, even in Article 4 of Constitution Number 39 Year 1999 concerning Human Rights (Undang-Undang Nomor 39 Tahun 1999 tentang Hak Asasi Manusia), it is stated that the right to life, the right not to be tortured, the right to personal, mind and conscience freedom, the right to adhere religion, the right not to be enslaved, the right to be recognized as a person and equality before retroactive law are human rights that cannot be reduced under any circumstances and by anyone. In article 22 section (1) it is stated that everyone is free to embrace their respective religions and to worship according to their religions and beliefs. Then in section (2) it is stated that the state guarantees the freedom of everyone to embrace their respective religions and to worship according to their religions and beliefs. On the higher level of constitution, stated that everyone is free to embrace a religion and worship according to their religions, choose education and teaching, choose a job, choose citizenship, choose a place to live in the territory of the country and leave it, and have the right to return (UndangUndang Dasar Negara Republik Indonesia Tahun 1945 (2002) pasal 28 and The state guarantees the freedom of each resident to embrace his own religion and to worship according to his religion and belief ((Undang-Undang Dasar Negara Republik Indonesia Pasal 28 E Ayat (2)).

That's how deep society's religiosity is regulated because looking at various religious scriptures, books and teachings, one would find that all religion strongly motivate ethical behaviors; doing good is typically seen as essential principle (Kuah-Pearce \& Cornelio, 2015, p.350) and morality thus affecting people's behavior and decision making (Singh, 2001, p.46; Saeed et al., 2001, p.127-142). Even, in broader scope such as nationalism, there is a positive correlation between religiosity and political tolerance (Kurd, 2018, p. 81). In depth interviews indicate that religious leader, especially in Indonesia which has various religion, more openly encouraged religious tolerance in religious diverse (Dowd, 2014, p.617). Started from religiosity as a good character, students can develop several character traits deemed worthy for universal citizens: respect for diverse worldviews, desire for peaceful solutions, and empathy toward people of different cultures (Lee \& Manning, 2013, p.285). Beside tolerance like what had been explained before, a good religiosity also pushed to a giving habit. Citizens in countries with a higher level of religious heterogeneity are more likely to engage in religious giving (Wiepking et al., 2014, p.640).

The religiosity of students is influenced by internal and external factors. Internal factors include the emotional relationship between parents and children, the child's age, and the pressure which is the source of abnormal psychiatric symptoms. The external factors include the family religious culture, institutional environment in the form of formal institutions such as schools or non-formal institutions such as TPA extracurricular activities, and the community. Thus, parents, teacher, and other professional 
can attest to the necessity of promoting positive character traits among children (Gilead, 2011, p.98; Lee \& Manning, 2013, p.284; Wringe, 2006, p.13), one way that can be reached is by instilling religiosity in students.

Character development, including religious character, is a lifelong process (Rusydiyah, 2014, p.227) and it isn't instantaneous, thus it should be begin in early childhood (Berkowitz \& Grych, 2000; Lee \& Manning, 2013; Wibowo \& Gunawan, 2015; Zubaedi, 2011). Based on developmental theory of Piaget's cognitive concept, since the first to third grade of primary school, student began the operation concrete stage which they get and use their knowledge with some logical or reasonable things. That logical thing obtained through activities that are concrete and meaningful (Anderiani et al., 2015, p.34; Shaffer \& Kipp, 2010, p.55). Therefore, character development is an effort that needs to involve character education centers, be it family, schools, and communities that run in an integrated manner since early childhood. Character education will be successful if the family, school, and community have character. Related to the context of this research, it means that religious character will also be successfully instilled in students if the family, school, and community are also religious, mainly because for Muslim, religious practice associated with extended family structure (Anthony et al., 2014, p.99).

There are five education areas that can foster good character: family, self, government, school, environment, and society. The idea of family is the idea of being together. Therefore, as long as togetherness is to be achieved, the household must be continuously fostered, all family members feel at home, and the children remain under the observation, care and guidance of their parents. Coaching can be done through the good family religious culture.

Family religious culture is the the whole system of ideas and feelings, actions, and works produced by humans in social life through the process of religious learning (Koentjaraningrat, 2003, p.72). A culture will naturally be passed from one generation to the next. As a consequence, it is not enough that the instillment of religious values in children is given only through lessons, deffinitions, explanation and understanding and then let the children walk alone (Kurniawan, 2013, p.84-85). Instilling religious values in children requires guidance, that are efforts to guide, direct, and assist children in certain matters, especially when the child feels helpless or when the child is experiencing a problem that he feels heavy. Thus, the presence of parents in guiding the children through the formation of a good family religious culture will be very meaningful and memorable for their children.

TPA activities in schools are also a factor that influences children's religiosity. Psychologically, elementary school age is conducive enough to receive guidance to read and memorize Al-Qur'an and to instill the values in it. The learning atmosphere and learning process are adapted to the world and the characteristics of a playful personality. The choice of the term "taman" refers to the psychological principle, because "taman" is a place that is conducive to play and fun. Even so, it requires the discipline in following this extracurricular activity. Discipline is an action that shows orderly behavior and obeys various provisions and regulation (Paimun \& Masruri, 2014; Setiawan et al., 2019). Discipline of behavior will affect the students to learn (Rusydiyah, 2014, p.230), that is why discipline has to begin since early age (Gregory \& Fergus, 2017, p.117). Thus, it is hoped that TPA will have a positive impact on effort to foster students' religiosity since they're in the first-grade.

After knowing the importance of religious values to be instilled in students since early and the factors that influence it, it is appropriate for parents and teachers to work together in an effort to instill it. Thus wherever the students are, either at school or at home, they still get the same frame of education and mutually sustainable while completing each other. Not only by giving advice, many methods can be done to instill this value, but it can be done through parents and teachers become model for their children or through joyful learning where religious value can be inserted (Khan, 2018, p.179).

Unfortunately, the fact shows the gap between theories and realities. Students had heterogeneous backgrounds, thus they showed heterogeneous attitude and thoughts in all aspect of life. The background referred in this context was the socio-economic condition of the family and the cultural environment in which they lived. According to the religious education teacher's point of view, these two factors played a major role in shaping students' character, including their religiosity. It wasn't all parent paid attention and supported the students learning process at home, both academic and non-academic, for instance supporting TPA in an earlier age, even though TPA had become a compulsory extracurricular for every primary school in Pengasih. It could be seen from some students' ability which doesn't progressive, even though the other students who were always monitored at home had a good progress. Almost all of primary teacher in Pengasih had hold a coordination with parents, either directly face to face or through 
social media, but some of them remain indifferent to their children's learning development because they were tired of working all day long or unable to keep up their learning process.

Students' awareness in religious aspect was still bad, especially for carrying out compulsory worship in the form of prayer for Moslem. For example, at SDN 2 Karangsari and SDN Sendang which implemented the obligatory regulation of holding $d z u h u r$ prayer together at school everyday: the second and third grade were every Monday, the fourth grade were every Tuesday, the fifth grade were every Wednesday, and the sixth grade were every Thursday, while the first-grade had not scheduled because their class up before prayer time. Even so, because their uniforms were majority short-sleeved, the boys often didn't carry sarongs while the girls didn't carry mukena, thus they hide from their teacher to carry out $d z u h u r$ together.

The five-days-work system nowadays in Kulon Progo made the school difficult in adjusting the customary schedule for congregational prayer and TPA extracurricular, because there were six classes with five days only. Matching schedule for two classes in one day might be a solution, but the TPA teachers stated that it didn't work effectively. TPA teachers should teach the students one by one for an optimum result.

Students had lack of motivation and awareness in studying Al Qur'an. A semi-structured interview held with some students and showed that they were attending TPA just because their score will be included in learning outcome report. They also didn't study first before following test in reading Al Qur'an. There were even some students who didn't learn Al Qur'an at home because their parent couldn't teach them or there was no TPA program in their neighborhood.

Related to the religious culture and the discipline in attending TPA at school above, researcher also found that students didn't have a good morality, especially in term of manners. Researcher found that students speak harshly, eat and drink while standing, cursing their friends, and even cursing their teachers.

Based on data collection through observation and interview, various problem that are actually happen in first-grade students in SDN 2 Karangsari and SDN Sendang have the potential to be experienced by the other school in Pengasih. Thus, by not intending to rule out the other problems, this study is limited in the form of a bad religiosity of first-grade students. Finally, this study was conducted to understand the effect of family's religious culture and the discipline in attending TPA at school both partially or simultaneously toward first-grade students of primary school's religiosity.

\section{Method}

This study adopted the expost facto quantitative approach with questionnaire instruments in order to find out the effects of family's religious culture and the discipline in TPA at school on the first-grade students' religiosity. This study was based on an assumption that a symptom can be classified and the symptom relationship is causal, therefore there were three focus variables in this study, such as students' religiosity as dependent variable (Y), family's religious culture (X1) and student's discipline in attending TPA at school (X2) as independent variables. It can be drawn in schematic form as Figure 1.

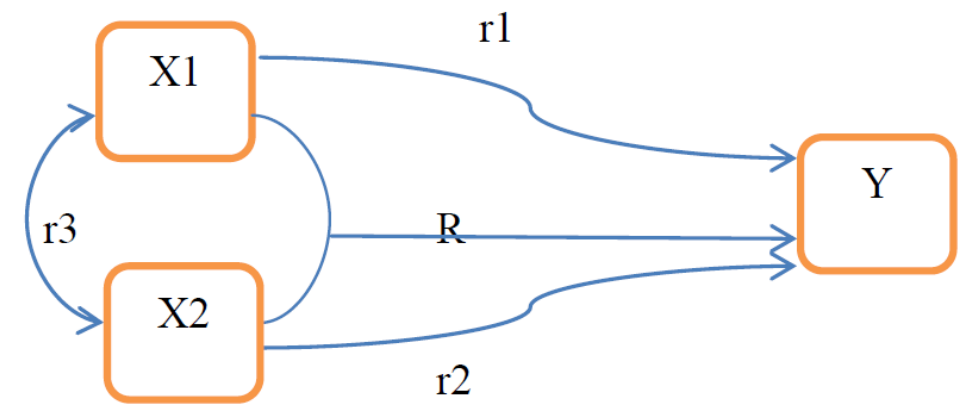

Figure 1. Study Paradigm

Notes:

$\mathrm{X} 1 \rightarrow$ Family's Religious Culture

$\mathrm{X} 2 \rightarrow$ The Discipline in Attending TPA

$\mathrm{Y} \rightarrow$ Students' Religiosity 
The respondents were 238 of 585 first-grade students of primary school in Pengasih District, Kulon Progo regency. Sampling technique used was stratified random sampling. This kind of sampling is done by taking a sample from each group whose number is adjusted randomly to the number of members in each grup. There were six groups of primary school in Pengasih District, thus there were six stratas taken.

There were three instruments with four choices in this study, such as family's religious culture, the discipline in attending TPA at school, and students' religiosity. Students as respondents had to choose one of the answers: (1) always; (2) often; (3) sometime; (4) never.

Instruments' validity and reliability test was conducted by IBM SPSS 23 version. The validity was tested using Pearson product moment correlation, while the reliability test was done by considering Cronbach's Alpha. Instrument items would be valid if it scores was more than 0.3 and it could be reliabile if it scores ranged between $0.6-1$ (0.6-0.8: enough; 0.8-1: high).

Table 1. Instrument's Validity Test

\begin{tabular}{cccccc}
\hline X1 & Corrected ITC & X2 & Corrected ITC & Y & Corrected ITC \\
\hline 1 & .471 & 1 & .425 & 1 & .495 \\
2 & .526 & 2 & .352 & 2 & .487 \\
3 & .392 & 3 & .358 & 3 & .425 \\
4 & .422 & 4 & .457 & 4 & .507 \\
5 & .608 & 5 & .560 & 5 & .515 \\
6 & .401 & 6 & .398 & 6 & .711 \\
7 & .392 & 7 & .423 & 7 & .586 \\
8 & .368 & 8 & .361 & 8 & .487 \\
9 & .417 & 9 & .463 & 9 & .711 \\
10 & .526 & 10 & .421 & 10 & .586 \\
11 & .471 & 11 & .417 & 11 & .711 \\
12 & .422 & 12 & .499 & 12 & .711 \\
13 & .608 & 13 & .544 & 13 & .495 \\
14 & .496 & 14 & .415 & 14 & .515 \\
15 & .471 & 15 & .339 & 15 & .361 \\
16 & .405 & 16 & .492 & 16 & .495 \\
17 & .422 & 17 & .568 & 17 & .361 \\
18 & .401 & - & - & 18 & .507 \\
- & - & - & - & 19 & \\
\hline
\end{tabular}

Table 1 showed the valid instruments that had been used in this study. By considering the Corrected Item-Total Correlation (Corrected ITC) above, every point of instrument was more than 0.3, it means that instrument items used were valid.

Table 2. Instrument's Reliability Test

\begin{tabular}{rccc}
\hline & X1 & X2 & Y \\
\hline Cronbach's Alpha & .830 & .836 & .887 \\
\hline
\end{tabular}

Table 2 showed that each variables had a high reliability because it scores ranged between $0.8-1$. It means that the instrument items were very reliable.

The analysis technique used in this study were prerequisite analysis test (including: (1) normality test; (2) linearity test; and (3) multicollinearity test;) and hypothesis testing. The normality test is carried out using the Kolmogrov-Smirnov Test by IBM SPSS $23^{\text {rd }}$ version. If the significance score is up to 0.05 or more, it means that the data is distributed normally. The linearity test is carried out using Test of Linearity by IBM SPSS $23^{\text {rd }}$ version. If the significance linearity is under 0.05 and the significance deviation of linearity is up to 0.05 or more, thus the variables have a linear relationship. The multicoliearity test is carried out to find out the tolerance dan Variance Inflation Factor (VIF) score. If the alpha or tolerance score is $10 \%$ or 0.10 , so the VIF is 10 . From the result of $\mathrm{VIF}_{\text {count }}<\mathrm{VIF}=10$ and all the tolerance score of independent variables are up to $10 \%$, it can be concluded that there is no multicolinearity between them.

The data analysis in hypothesis testing used is multiple regression with the basic of decision making by compared $t_{\text {counted }}$ with $\mathrm{t}_{\text {table. }}$. If $\mathrm{t}_{\text {counted }}<\mathrm{t}_{\text {table, }}$, so Ho is accepted while Ha is rejected. Otherwise, if $t_{\text {counted }}>t_{\text {table, }}$, so Ho is rejected while Ha is accepted. 
Jurnal Prima Edukasia, 9 (1), 2021 - 150

Tampi Prehadini, Anwar Senen, Ali Mustadi

\section{Result dan Discussion}

Result

The results of the study are presented consecutively on each component such as students' religiosity, family's religious culture, and the discipline in attending TPA at school.

Students' Religiosity

Students' religiosity was revealed using a psychological instrument with 19 questions.

Table 3. Students' Religiosity Data

\begin{tabular}{|c|c|c|}
\hline No. & Indicator & Percentage $(\%)$ \\
\hline 1. & Commitment to Allah commandments and prohibition & 16 \\
\hline 2. & Eager to study religious discussion & 11 \\
\hline 3. & Active in religious activities & 5 \\
\hline 4. & Appreciate religious symbols & 16 \\
\hline 5. & Familiar with Al Qur'an & 5 \\
\hline 6. & Honest & 11 \\
\hline 7. & Fair & 5 \\
\hline 8. & Useful for others & 16 \\
\hline \multirow[t]{2}{*}{9.} & Humble & 15 \\
\hline & Total & 100 \\
\hline
\end{tabular}

Table 3 showed the contribution of each indicator of attitude and behavior which indicated that a student has good religiosity. The biggest indicators that showed the signs of religiosity were student's commitment to Allah's commandments and prohibition, appreciate religious symbols, and useful for others. Based on Table 3, the histogram can be described as Figure 2.

First Grade Students' Religiosity

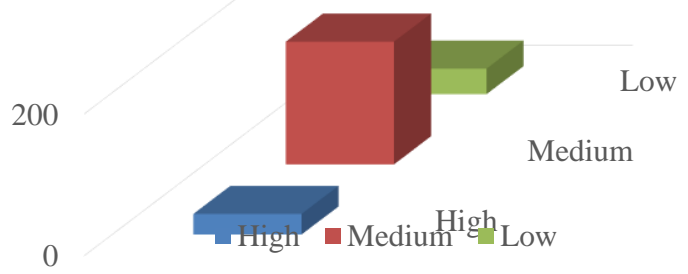

Figure 2. Histogram of Students' Religiosity Frequency Distribution

Figure 2 showed that the turn of first-grade students' religiosity in Pengasih District was medium, low, and high. While majority students were available in medium level. It means that students' religiosity level has not been good enough.

Family's Religious Culture

Family's religious culture was revealed using a psychological instrument with 18 questions.

Table 4. Family's Religious Culture Data

\begin{tabular}{clc}
\hline No. & \multicolumn{1}{c}{ Indicator } & \multicolumn{1}{c}{$(\%)$} \\
\hline 1. & Always adhere to Al Qur'an and hadiths & 11 \\
2. & Fostering a tolerance in adherents of another's faith & 11 \\
3. & Parents educate children regarding to the importance of religiosity & 11 \\
4. & Parents train the children to fast since an early age & 5 \\
5. & Parents guide the children to carry out the obligatory prayer & 11 \\
6. & Parents guide the children to pay zakat and sharing with others & 11 \\
7. & Family members pray before and after do some activities & 11 \\
8. & Each family member have prayer equipment & 6 \\
9. & Each family member have Al Qur'an and juz 'amma & 11 \\
10. & Calligraphy becomes home decoration & 6 \\
11. & Family has religious book collection & 6 \\
& Total & 100 \\
\hline
\end{tabular}


Table 4 showed the contribution of each indicator of attitude and behavior which indicated that a family has a good religious culture. The biggest indicators that showed the signs of religious culture were always adhere to Al Qur'an and hadiths, fostering a tolerance in adherents of another's faith, parents educate children regarding to the importance of religiosity, parents guide the children to carry out the obligatory prayer, parents guide the children to pay zakat and sharing with others, family members pray before and after do some activities, and each family member have Al Qur'an or juz 'amma. Based on the Table 2, the histogram can be described as Figure 3.

Family's Religious Culture

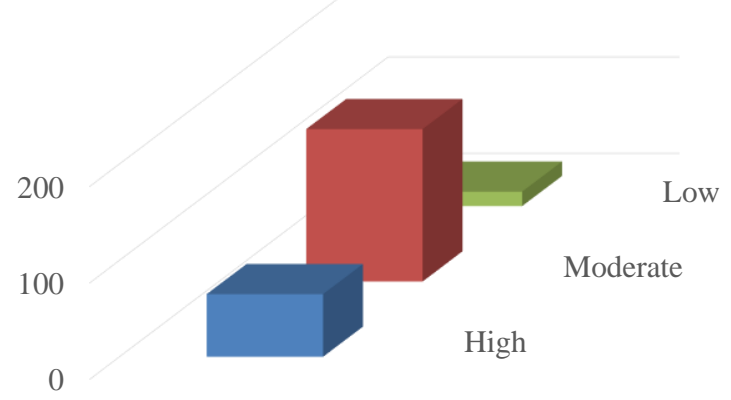

- High - Moderate $\square$ Low

Figure 3. Histogram of Family's Religious Culture Frequency Distribution

Figure 3 showed that the turn of the first-grade students' family religious culture in Pengasih District was medium, high, and low. While majority students were available in medium level. It means that their family's religious culture level has not been good enough.

\section{The Discipline in Attending TPA at School} questions.

The discipline in attending TPA at school was revealed using a psychological instrument with 17

Table 5. The Discipline in Attending TPA Data

\begin{tabular}{clc}
\hline No. & \multicolumn{1}{c}{ Indicator } & $(\%)$ \\
\hline 1. & Come and go home on time & 5 \\
2. & Follow the activities accrding to the schedule & 11 \\
3. & Students do not left TPA before it ends & 11 \\
4. & Students submit the assignment on time & 12 \\
5. & Students are calm during the activity & 11 \\
6. & Students finish the tasks responsibly & 12 \\
7. & Students pay attention to the explanation related to hijaiyah letter, tajwid, memorizing juz 'amma & 14 \\
8. & and daily prayers, fiqh, and monotheism & 6 \\
9. & Students are active in following TPA & 6 \\
10. & Students hear the uniform according to the schedule & fiqh, and monotheism to learn hijaiyah letter, tajwid, memorizing juz 'amma and daily prayers, \\
& Total & 12 \\
\hline
\end{tabular}

Students' Discipline in Attending TPA

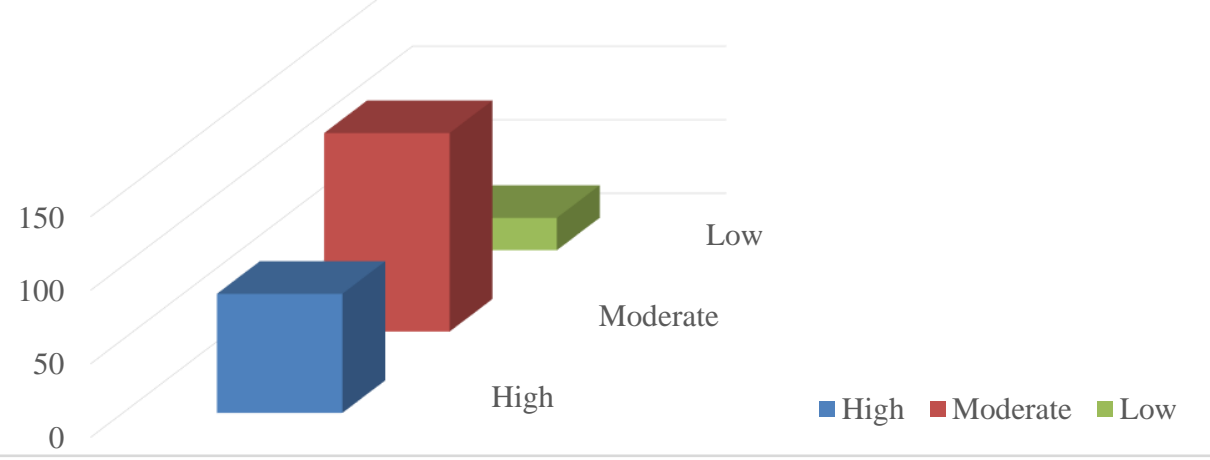

Figure 4. Histogram of The Discipline in Attending TPA 
Table 5 showed the contribution of each indicator of attitude and behavior which indicated student's discipline in attending TPA at school as an extracurricular activity. The biggest indicators that showed the signs of discipline was students pay attention to the explanation related to hijaiyah letter, tajwid, memorizing juz 'amma and daily prayers, fiqh, and monotheism. Based on the Table 3, the histogram can be drawn as Figure 4.

Figure 4 showed that the turn of the first-grade students' discipline in attending TPA at school was medium, high, and low. While majority students were available in medium level. It means that their discipline has not been good enough.

\section{Prerequsite Analysis Test}

Normality, linearity, and multicollinearity are prerequisite test before carrying out a multiple regression. Here are the results of prerequisite analysis test that had been done.

Table 4. Normality Test

\begin{tabular}{|c|c|c|c|c|}
\hline \multirow[b]{2}{*}{ Data } & \multicolumn{3}{|c|}{ Kolmogorov-Smirnov } & \multirow[b]{2}{*}{ Conclusion } \\
\hline & $\mathrm{Chi}^{2}$ & Df & Sig. & \\
\hline Students' religiosity & 4.864 & 5 & 0.433 & Normally distributed \\
\hline Family's religious culture & 5.664 & 5 & 0.340 & Normally distributed \\
\hline The discipline in attending TPA & 4.773 & 5 & 0.444 & Normally distributed \\
\hline
\end{tabular}

Asymp. Sig score from those three variables was more than 0.05 , thus the data were normally distributed.

Table 5. Linearity Test

\begin{tabular}{lllll}
\hline & Variables & & \multicolumn{2}{c}{ Linearity } \\
\hline \multicolumn{1}{c}{ Independent } & Dependent & Df & Sig. & Dev Sig. \\
\hline Family's religious culture & Students' religiosity & 33 & 0.00 & 0.273 \\
The discipline in attending TPA & Students' religiosity & 32 & 0.003 & 0.302 \\
\hline
\end{tabular}

The test result showed that the significance point of linearity was less than $0.05(0.00<0.05)$, while the significance point of deviation from linearity was more than $0.05(0.273>0.05)$. Then the result of the discipline in attending TPA toward students' religiosity had a significance point of linearity less than $0.05(0.003<0.05)$ and a significance point of deviation from linearity more than $0.05(0.302$ $>0.05)$. So that, we can conclude that the data was linear.

Table 6. Multicollinearity Test

\begin{tabular}{|c|c|c|c|}
\hline \multirow{2}{*}{ Data } & \multicolumn{2}{|c|}{ Noncolinearity } & \multirow[t]{2}{*}{ Multicollinearity } \\
\hline & Tolerance & VIF & \\
\hline Family's religious culture & 0.937 & 1.067 & - \\
\hline The discipline in attending TPA & 0.937 & 1.067 & - \\
\hline
\end{tabular}

Tolerance point was more than $0.10(0.937>0.10)$ and VIF was less than $10(1.067<10)$, thus there was no multicollinearity between the independent variables.

Hypothesis Test

Partially effect of family's religious culture toward students' religiosity

Table 7. Partially Test of Family's Religious Culture

\begin{tabular}{lcccc}
\hline \multirow{2}{*}{ Variable } & \multicolumn{3}{c}{ Partially Test } \\
\cline { 2 - 5 } & Cor. Coef & $\mathrm{r}^{2}$ & $\mathrm{t}_{\text {count }}$ & Sig. \\
\hline Fanily's religious culture & -0.210 & 0.044 & -3.249 & 0.0001 \\
\hline
\end{tabular}

The partial correlation coeffition was $-0.210 ; \mathrm{r}^{2} \mathrm{X}_{1} \mathrm{Y} . \mathrm{X}_{2}$ point was $0.044 ; \mathrm{t}_{\text {count }}-3,249$; and the significance score was 0.001 . It means that the ability of family's religious culture in explaining the variance of students' religiosity was $4.4 \%$. So, there were $95.6 \%$ variances of family's religious culture that explained by another variable.

$\mathrm{T}_{\text {count }}$ was -3.249 ; while $\mathrm{t}_{\text {table }}$ was 1.65 . if both of them compared, $-\mathrm{t}_{\text {count }}<-\mathrm{t}_{\text {table }}(-3.249<-1.65)$. It means there were an effect of family's religious culture toward students' religiosity. The significance score was 0.001 and it was less than $0.05(0.001<0.05)$ so there was a significant effect from family's 
Jurnal Prima Edukasia, 9 (1), 2021 - 153

Tampi Prehadini, Anwar Senen, Ali Mustadi

religious culture toward students' religiosity. Therefore, $\mathrm{H}_{0}$ was rejected, family's religious culture partially had a significant effect toward students' religiosity.

Partially effect of the discipline in attending TPA at school toward students' religiosity

Table 8. Partially Test of the Discipline in Attending TPA

\begin{tabular}{ccccc}
\hline \multirow{2}{*}{ Variable } & \multicolumn{3}{c}{ Partially Test } \\
\cline { 2 - 5 } & Cor. Coef & $\mathrm{r}^{2}$ & $\mathrm{t}_{\text {count }}$ & Sig. \\
\hline Discipline in attending TPA & -0.008 & 0.001 & -0.139 & 0.889 \\
\hline
\end{tabular}

The partial correlation coefficient was $-0.008 ; \mathrm{r}^{2} \mathrm{X}_{1} \mathrm{Y} . \mathrm{X}_{2}$ point was $0.001 ; \mathrm{t}_{\text {count }}-0.139$; and the significance point was 0.889 . If compared with $\mathrm{t}_{\text {table }}$ which was 1.65 , so $-\mathrm{t}_{\text {count }}>-\mathrm{t}_{\text {table }}(-0.139>-1.65)$. Therefore, there was no effect from the discipline in attending TPA at school toward students' religiosity.

The result of significance point was 0.889 ; and because it was more than $0.05(0,889>0,05)$ so the discipline in attending TPA at school partially didn't have a significant effect toward students' religiosity. Therefore, $\mathrm{H}_{0}$ was accepted.

Simultaneously effect of family's religious culture and the discipline in attending TPA at school toward students' religiosity

Table 9. Simultaneously Test of the Independent Variables

\begin{tabular}{|c|c|c|c|}
\hline \multirow{2}{*}{ Model } & \multicolumn{3}{|c|}{ Anova } \\
\hline & $\mathrm{df}$ & $\mathrm{F}$ & Sig. \\
\hline Regression & 2 & 5.404 & 0.005 \\
\hline
\end{tabular}

The significance point was 0.005 and less than alpha $0.05(0.005<0.05)$. Thus, Ho was rejected while Ha was accepted, it means family's religious culture and the discipline in attending TPA at school simultaneously had a significant effect toward students' religiosity. The amount of the effect was presented in Table 10.

Table 10. The Amount of Independent Variables Effect

\begin{tabular}{|c|c|c|c|}
\hline \multirow{2}{*}{ Model } & \multicolumn{3}{|c|}{ Summary } \\
\hline & $\mathrm{R}$ & $\mathrm{R}^{2}$ & Adjusted $\mathrm{R}^{2}$ \\
\hline 1 & 0.228 & 0.052 & 0.042 \\
\hline
\end{tabular}

The amount of independent variables effect toward students' religiosity could be seen trough $\mathrm{R}^{2}$ score. The $\mathrm{R}^{2}$ score 0.052 showed that the effect of family's religious culture and the discipline in attending TPA at school simultaneously had $5.2 \%$ effect, while $94.8 \%$ variables didn't explain in this study.

\section{Discussion}

The study findings prove that family's religious culture partially has a significance effect toward students' religiosity. This conclusion is drawn based on the result of significance test which is 0.001 .

This data analysis is congruent with two of eight functions of family which stated National Family Planning Coordination Agency (BKKBN), such as educational and religional function. In carrying out the educational function, family acts as the best role for childrens' socialization and education. Family's education actually become a core and foundation for childrens' development. Meanwhile, the education that got from school or social environment is only a small part of whole education. On the ather track, in carrying out the religional function, family acts to foster religious life, namely having faith and being obedient to God. Every step taken by family should always be based on their religion rule (BKKBN, 2005).

Al-Ghazali (Hasan, 2003) assesses the most important role of the family is educational function as a pathway for the development of basic religious value when the child still under five years old, as a continuation of the potential fitrah that the child carries since they born. Instilling Islamic education values since an early age or toddler becomes the formation of a child's personality that has a very big influence. Parents' experiences greatly influence the instilling of religious education and personality development for children. Family centered positive behavior support acknowledges that parents can be and are experts regarding their child behavior (Dunlap et al., 2017, p.18). 
The dominant period in arranging children's character and personality happens in family. This phase starts from childhood to early adulthood (Kurniawan, 2013, p.84-85). In this phase, children have a tendency to imitate their environment's values and behavior, take behavior patterns, and new values as well as the growth of idealism in order to solidify self-identity. If there is an instilling values process in that phase which are perfectly summarized in character education, including religious values, it will become the basic foundation as well as children personality when they grow up. The description before also applies to raise students' religious awareness. It is not enough yet to give religious values for students through explanation, understanding, and learning and then let them study it by themselves. Instilling religious values for students requires a guidance, such as effort to guide and help them in certain things, especially when they feel helpless or have any problem. So, the presence of their parents in guiding them will be very meaningful and memorable.

Families are expert on their child; it includes their culture, their environment, and of course themselves, and have invaluable information to contribute. Thus, family should play a role in all aspects of the model for effective implementation (Dunlap et al., 2017, p.17-22). Then, we as the facilitator have to make sure that families are fully invested and that everyone has the same goals or visions for children. As Lickona said, one of adults' fundamental responsibility is to sustain the civilization by passing on the values that are the foundation of the society (Lee \& Manning, 2013, p.284; Lickona, 2000, p.48).

The second finding shows that the discipline in attending TPA at school partially didn't have a significant effect toward students' religiosity. It means the increase or decrease of students' religiosity is not affected by the discipline in attending TPA at school. This conclusion is based on the significance score such as 0.889 .

Following TPA at school is very likely to have a positive impact on students, but it can not be concluded just like that, it should consider that there are so many factors that influence it (White \& Warfa, 2011, p.58). Interview was conducted with first-grade students of primary school in Pengasih District, Kulon Progo Regency whose samples were taken randomly and they said that the TPA schedule after school was quite tiring. Students felt tired after studying for approximately five hours, but still have to take part in TPA extraxurricular. As a result, students felt compelled in attending TPA. This means that they were attending it just to meet the demand from the school and parents, but they did not feel the effectiveness of it.

This finding congruent with Gay Hendrick \& Kate Ludeman (Agustin, 2013, p.249) who states that one indicator of someone having religiosity is balanced with high discipline that grows form a passionate spirit and awareness, not from compulsion. In the other hand, if the discipline grows based on a compulsion, so someone can not have any religiosity in itself. In the context of TPA extracurricular, this was very likely to happen due to its schedule which was after school and the students already feel tired. This argument is in line with the opinion which states that a fresh and healthy physical condition will successful the learning process (Suryabrata, 1998, p.233).

Hollingswort (in Rachman, 1997, p.191-194) stated that one thing that can interfere the discipline is passive or low motivational students who come to the TPA moderately. With a tired and unfit condition as discussed above, it is very possible for students to come and leave TPA up to them and ignore the obligation there. Moreover, they attend it moderately only. This finding deserved a special attention, especially from the principal and teachers, either school teacher or TPA teacher that however education served as a best tool in teaching religion (Sulaiman, 2016, p.85), religious service attendance in the form of TPA for example, as an extracurricular is positively related to good behavior (Wright, 2016, p.23). The harmonious cooperation among all people in school is essentially needed in managing the schedule of TPA (Anwar et al., 2020, p.1).

The third finding showed that family's religious culture and the discipline in attending TPA at school simultaneously had a significant effect toward students' religiosity. This was indicated by the contribution of both of them such as $5.2 \%$ toward students' religiosity and had a significance value of 0.005 .

Parents' attitude and behavior will be a kind of blue print for how children act (Kurniawan, 2013, p.84). They who are diligent in praying at the mosque and reciting Al Qur'an will easily make their children pray and read Al Qur'an. They who always talk and behave politely will find it easier to remind their children to talk and behave politely too. Likewise, they who love giving will be a good lesson and experience for their children. Parents' good habits based on religious values will become an example 
for their children. Even so, instilling religious values is not easy. Good cooperation and coordination between parents, teachers, and society is really needed.

Religious value can also be taught at school through some religious habituation activities such as praying, thanking God, celebrating religious day, and doing obligatory pray together. A lot of activities at the school's mosque can be done to make students have religiosity, such as praying dzuhur together everyday, following TPA, and praying Jumuah together for the boys. Religious education in the form of Pendidikan Agama Islam (PAI) also has to be done effectively like Mahatma Gandhi's ideal that religious studies are a good a forum as any other for promoting a good life (Damm, 2011, p.9-10).

Religious activities will lead students to accustomed religious behavior. By the mentioned activities above, especially read and write Al Qur'an in which it is targeted that there is guidance for students in reading Al Qur'an according to tajwid, lead them to be more diligent in worshiping, have a good moral, and the last hope is tolerance, harmonious, and peaceful life can be established (Kurniawan, 2013, p.129). In addition, PAI teacher who usually acts as the coordinator of TPA should teach happily (Rusydiyah, 2014, p.230).

\section{Conclusion}

Based on the results above, family's religious culture partially has a significant effect toward firstgrade students' religiosity. It means that the better family's religious culture, the better stuents' religiosity. A better religiosity in this context is not only limited to practical understanding, but also easy in instilling it. This conclusion is based on the assumption that children imitate their family, especially their parents. On the other hand, unfortunately students' discipline in attending TPA at school partially doesn't has any significant effect toward their religiosity because TPA schedule after school is considered ineffective from students' perception. Students are already tired, their energy has been used up for studying since morning, so their attendance at the TPA is only meeting school's demand, considering that the extracurricular value is also included in their learning report. However, if both of them are combined, they will give a significant effect toward students' religiosity. Thus, it needs to be noted that parents and teachers have to work together in forming a religious climate for students wherever they are, both at home and at school.

According to the conclusion, there are some recommendations for parents, school, and the next researcher in order to build students' religiosity. First recommendation is addressed to parents. Parents are expected to build a religious culture through religious exemplary since their children in an early age, both in terms of thought, behavior, and the existence of religious symbols in home. Then, to make it balance, school has to evaluate and improve the implementation of TPA by rescheduling it to when students still feel fresh to study.

While for further researcher, it can be noted that this study reveals that students' religiosity is $5.2 \%$ influenced by family's religious culture and the discipline in attending TPA at school. Thus, there are $94.8 \%$ of other factors that able to explain variance of religiosity. It is possible for the next researcher to reveal the other factors that influence religiosity.

\section{References}

Agustin, A. G. (2003). Rahasia sukses mengembangkan ESQ Power: Sebuah inner journey melalui ihsan. Agra.

Anderiani, D., \& Wilujeng, I. (2015). Pengembangan subject spesific pedagogy tematik untuk menanamkan kedisiplinan dan kepedulian siswa SD kelas II. Jurnal Prima Edukasia, 3(1), 3345. https://doi.org/10.21831/jpe.v3i1.4063

Anthony, F.-V., Hermans, C. (Chris), \& Sterkens, C. J. A. (Carl). (2015). Religion and conflict attribution. In Religion and Conflict Attribution. BRILL. https://doi.org/10.1163/9789004270862

Anwar, H., Arsyad, L., \& Mobonggi, A. H. (2020). The management of culture and environment of madrasah: Its implementation and challenges in industrial revolution era 4.0. Jurnal Prima Edukasia, 8(2), 188-198. https://doi.org/10.21831/jpe.v8i2.33488

Azzet, A. M. (2011). Urgensi pendidikan karakter di Indonesia. Ar-Ruzz Media.

Berkowitz, M. W., \& Grych, J. H. (2000). Early character development and education. Early 
Jurnal Prima Edukasia, 9 (1), 2021 - 156

Tampi Prehadini, Anwar Senen, Ali Mustadi

Education \& Development, 11(1), 55-72. https://doi.org/10.1207/s15566935eed1101_4

BKKBN. (2005). Keluarga berencana dan kesehatan reproduksi. Badan Keluarga Berencana Nasional.

Cao, N. (2018). The rise of field studies in religious research in the People's Republic of China. China Review, 18(1), 137-164.

Damm, A. (2011). Mahatma Gandhi and character education in non-violence: Its relevance in religious studies today. Teaching Theology \& Religion, 14(1), 3-12. https://doi.org/10.1111/j.14679647.2010.00667.x

Dowd, R. A. (2016). Religious diversity and religious tolerance. Journal of Conflict Resolution, 60(4), 617-644. https://doi.org/10.1177/0022002714550085

Dunlap, G., Strain, P. S., Lee, J. K., Joseph, J. D., Vatland, C., \& Fox, L. (2017). Prevent-teachreinforce for families: A model of individualized positive behavior support for home and community. Brookes Publishing.

Efaningrum, A. (2009). Laporan penelitian kajian kultur sekolah yang kondusif bagi perlindungan anak.

El Kurd, D. (2018). Religiosity and its political effects. AlMuntaqa, 1(2), 81. https://doi.org/10.31430/almuntaqa.1.2.0081

Ferdiawan, E., \& Putra, W. E. (2013). Esq education for children character building based on phylosophy of Javaness in Indonesia. Procedia - Social and Behavioral Sciences, 106, 10961102. https://doi.org/10.1016/j.sbspro.2013.12.123

Gilead, T. (2011). Countering the vices: on the neglected side of character education. Studies in Philosophy and Education, 30(3), 271-284. https://doi.org/10.1007/s11217-011-9223-1

Glock, C. Y., \& Stark, R. (1966). Religion and society in tension. Rand McNally \& Company.

Gregory, A., \& Fergus, E. (2017). Social and emotional learning and equity in school discipline. Future of Children, 27(1), 117-136. https://doi.org/10.1353/foc.2017.0006

Hasan, M. T. (2003). Islam dan masalah sumber daya manusia. Lantabora Press.

Iswara, M. A. (2020, July). Indonesia ranks among most religious countries in Pew study. The Jakarta Post.

Khan, M. J. (2018). Construction of Muslim religiosity scale. Islamic Studies, 53(1-2), 67-81.

Koentjaraningrat, R. M. (2003). Pengantar antropologi I. Rineka Cipta.

Kuah-Pearce, K. E., \& Cornelio, J. S. (2015). Introduction: Religious philanthropy in Asia. Asian Journal of Social Science, 43(4), 349-355. https://doi.org/10.1163/15685314-04304002

Kurniawan, S. (2013). Pendidikan karakter konsepsi dan implementasi secara terpadu di lingkungan keluarga, sekolah, perguruan tinggi, dan masyarakat. Ar-Ruzz Media.

Lee, G.-L., \& Manning, M. L. (2013). Introduction: Character education around the world: encouraging positive character traits. Childhood Education, 89(5), 283-285. https://doi.org/10.1080/00094056.2013.830879

Lickona, T. (2000). Talks about character education. Scholastic Early Childhood Today, 14 (7), 48 49.

Paimun, P., \& Masruri, M. S. (2014). Pengembangan subject spesific pedagogy tematik untuk meningkatkan kejujuran dan kedisiplinan siswa kelas I SD. Jurnal Prima Edukasia, 2(2), 194 208. https://doi.org/10.21831/jpe.v2i2.2719

Rachman, M. (1997). Manajemen kelas. Departemen Pendidikan dan Kebudayaan.

Undang-Undang Dasar Negara Republik Indonesia Tahun 1945, (2002).

Rusydiyah, E. F. (2014). Character education through the constructivist design of Islamic education subject at Elementary School Pembangunan Jaya II in Gedangan Sidoarjo. Al-Ta Lim Journal, 21(3), 227-238. https://doi.org/10.15548/jt.v21i3.108

Setiawan, A., Fajaruddin, S., \& Andini, D. W. (2019). Development an honesty and discipline assessment instrument in the integrated thematic learning at elementary school. Jurnal Prima 
Jurnal Prima Edukasia, 9 (1), 2021 - 157

Tampi Prehadini, Anwar Senen, Ali Mustadi

Edukasia, 7(1), 9-19. https://doi.org/10.21831/jpe.v7i1.23117

Shaffer, D. R., \& Kipp, K. (2010). Developmental psychology: childhood and adolesence (8th ed.). Cengage Learning.

Shyan Fam, K., Waller, D. S., \& Zafer Erdogan, B. (2004). The influence of religion on attitudes towards the advertising of controversial products. European Journal of Marketing, 38(5/6), 537-555. https://doi.org/10.1108/03090560410529204

Singh, M. F. (2001). Honest living: A means to an end (4th ed.). Thompson Press.

Stedje, L. B. (2013). Nuts and bolts of character education. Literature Review, 3, 1-6.

Sulaiman, K. O. (2016). Religious violence in contemporary Nigeria: Implications and options for peace and stability order. Journal for the Study of Religion, 29(1), 85-103. https://doi.org/10.4314/jsr.v29i1

Suryabrata, S. (2010). Psikologi pendidikan. PT Rajagrafindo.

Undang-Undang Nomor 1 Penetapan Presiden Tahun 1965 tentang Penodaan Agama.

Undang-Undang Nomor 39 Tahun 1999 tentang Hak Asasi Manusia.

White, R., \& Warfa, N. (2011). Building schools of character: A case-study investigation of character education's impact on school climate, pupil behavior, and curriculum delivery. Journal of Applied Social Psychology, 41(1), 45-60. https://doi.org/10.1111/j.1559-1816.2010.00701.x

Wibowo, A., \& Gunawan, G. (2015). Pendidikan karakter berbasis kearifan lokal di sekolah (konsep, strategi, dan implementasi). Pustaka Pelajar.

Wiepking, P., Bekkers, R. H. F. P., \& Osili, U. O. (2014). Examining the association of religious context with giving to non-profit organizations. European Sociological Review, 30(5), 640-654. https://doi.org/10.1093/esr/jcu064

Wright, J. D. (2016). Why is contemporary religious terrorism predominantly linked to Islam? Four possible psychosocial factors. Perspectives on Terrorism, 10(1), 19-31.

Wringe, C. (2006). Moral education: Beyond the teaching of right and wrong. Springer Science \& Business Media.

Zubaedi, Z. (2011). Desain pendidikan karakter: Konsepsi dan aplikasinya. Kencana. 